\title{
Effects of climate change on thermal properties of lakes and reservoirs, and possible implications
}

\author{
G. B. Sahoo · S. G. Schladow • J. E. Reuter • \\ R. Coats
}

Published online: 9 July 2010

(c) The Author(s) 2010. This article is published with open access at Springerlink.com

\begin{abstract}
Meteorologic-driven processes exert large and diverse impacts on lakes' internal heating, cooling, and mixing. Thus, continued global warming and climate change will affect lakes' thermal properties, dynamics, and ecosystem. The impact of climate change on Lake Tahoe (in the states of California and Nevada in the United States) is investigated here, as a case study of climate change effects on the physical processes occurring within a lake. In the Tahoe basin, air temperature data show upward trends and streamflow trends indicate earlier snowmelt. Precipitation in the basin is shifting from snow to rain, and the frequency of intense rainfall events is increasing. In-lake water temperature records of the past 38 years (1970-2007) show that Lake Tahoe is warming at an average rate of $0.013^{\circ} \mathrm{C} /$ year. The future trends of weather variables, such as air temperature, precipitation, longwave radiation, downward shortwave radiation, and wind speed are estimated from predictions of three General Circulation Models (GCMs) for the period 20012100. Future trends of weather variables of each GCM are found to be different to those of the other GCMs. A series of simulation years into the future (2000-2040) is established using streamflows and associated loadings, and
\end{abstract}

G. B. Sahoo $(\varangle)$ · S. G. Schladow · J. E. Reuter · R. Coats

Tahoe Environmental Research Center, University of California, Davis, CA 95616, USA

e-mail: gbsahoo@ucdavis.edu

G. B. Sahoo · S. G. Schladow

Department of Civil and Environmental Engineering, University of California, Davis, CA 95616, USA

J. E. Reuter

Department of Environmental Science \& Policy, University

of California, Davis, CA 95616, USA meteorologic data sets for the period 1994-2004. Future simulation years and trends of weather variables are selected so that: (1) future simulated warming trend would be consistent with the observed warming trend $\left(0.013^{\circ} \mathrm{C} /\right.$ year $)$; and (2) future mixing pattern frequency would closely match with the historical mixing pattern frequency. Results of 40-year simulations show that the lake continues to become warmer and more stable, and mixing is reduced. Continued warming in the Tahoe has important implications for efforts towards managing biodiversity and maintaining clarity of the lake.

Keywords Climate change - General circulation model . Lake clarity model $\cdot$ Lake mixing dynamics - Water quality

\section{Introduction}

Meteorology is the driving force for lake internal heating, cooling, mixing, and circulation, which, in turn, affect nutrient cycling, food-web characteristics, fish-habitat, aquatic ecosystem, and other important features of lake/ reservoir limnology. Therefore, climate changes will affect the physical, chemical, and biological attributes of lakes and reservoirs (McCormick 1990; O'Reilly et al. 2003; Austin and Colman 2007, 2008) because of changes that include: (1) the thermodynamic balance across the airwater interface; (2) the amount of wind-driven energy input to the system; and (3) the timing of stream delivery into lake/reservoir. These processes can exert changes across the entire water column depth. The existing problems, such as water quality and quantity, may be exacerbated due to continued climate change.

Lake Tahoe, in the states of California and Nevada in the United States, is an ultra-oligotrophic and sub-alpine 
lake, and is renowned for its deep blue color and clarity. However, due to progressive loss of clarity, at the rate of $0.22 \mathrm{~m} /$ year (Tahoe Environmental Research Center (TERC) 2008), the lake has been the focus of major efforts by local, state, and federal agencies and policy-makers to halt the trend in clarity and trophic status. Moreover, records of the past 38 years (1970-2007) show that Lake Tahoe has become both warmer and more stable (Coats et al. 2006; Coats 2008). Air temperature and precipitation, and their hydrologic linkages (e.g. changes in streamflows, snowmelt timing) are most commonly examined to investigate the impact of climate change on water resources (e.g. Cayan et al. 2008; Siliverstovs et al. 2009; Zhang et al. 2009). To relate lake warming trend with climate change, shifts in trends of air temperature, snowfall percent to total precipitations, and snow melt timing in the basin are examined.

Trend slopes of maximum and minimum daily air temperature at the Tahoe City meteorological station are calculated using records of the past 57 years (1950-2006). To cancel out seasonal variations, 2-year moving average air temperature is presented in Fig. 1. Trends in Fig. 1 indicate that maximum and minimum air temperatures increase at 0.04 and $0.02^{\circ} \mathrm{C} /$ year, respectively. Five streams in the Tahoe Watershed (Upper Truckee River, Ward Creek, Trout Creek, Third Creek, and Blackwood Creek) have records long enough (1960-2005) to examine trends for the timing of the annual snowmelt peak discharge. Figure 2 shows that the timing of the spring snowmelt peak in the basin is shifting forward at a rate of about 0.4 days/year. The 103 years (1903-2005) of data shown in Fig. 3a suggest an increasing trend in the annual precipitation at Tahoe city. However, Fig. $3 b$ demonstrates that the percent of annual precipitation falling as snow on a day with average air temperature below freezing is in decreasing trend. The trend is highly significant with $p<0.0004$. The trends in air temperature, precipitation, percent of total annual precipitation falling as snow, and snowmelt timing indicate that the Tahoe basin is warming up. In response to such climate change, the lake has warmed up over the last 35 years (Fig. 4). Analyzing observed in-lake water temperature records of the past 38 years (1970-2007), Coats (2008) reported that: (1) the volume-weighted mean temperature of Lake Tahoe increases at an average rate of $0.013^{\circ} \mathrm{C} /$ year; and (2) the resistance of the lake to mixing increases. If this trend continues, the lake may ultimately be permanently stratified. Because of Lake Tahoe's large depth and volume, it stores much of the shortwave radiation striking on the lake surface and releases as latent and sensible heat and longwave radiation later on. With a low albedo and high heat storage capacity, Lake Tahoe never freezes. Lake Tahoe is an ice-free warm-monomictic lake, and
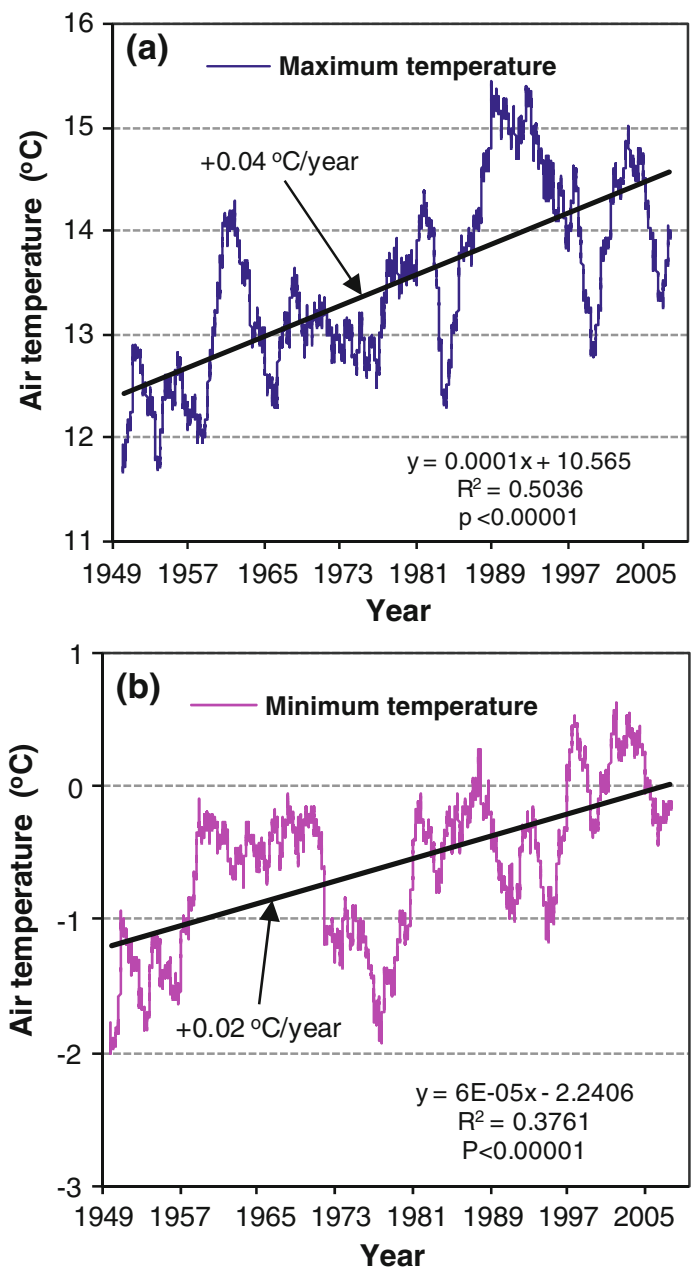

Fig. 1 Two-year moving average maximum and minimum air temperatures at Tahoe City. The values near the trend line show the increase in temperature per year

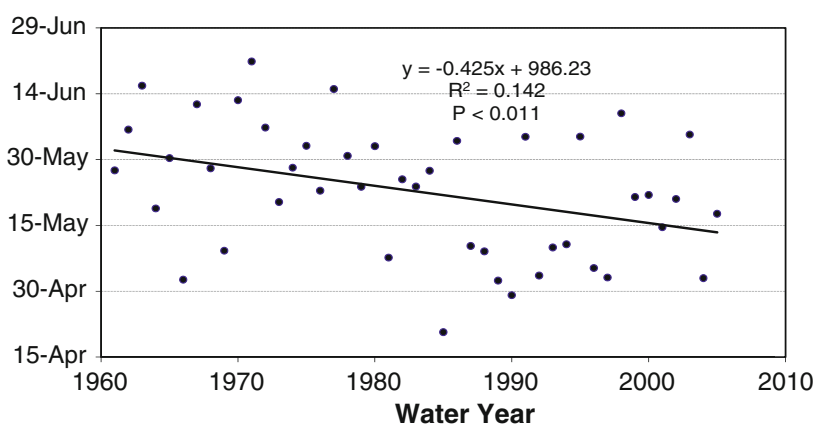

Fig. 2 Snowmelt peak discharge trend of five streams (Upper Truckee River, Ward Creek, Trout Creek, Third Creek, and Blackwood Creek) in the Lake Tahoe basin. The circular solid symbols and solid thick line represent average date of peak snowmelt and linear trend, respectively

deep mixing occurs only in the winter. Although Lake Tahoe deep winter mixing occurs once or twice in 3-4 years (TERC 2008), deep mixing might be stopped if 

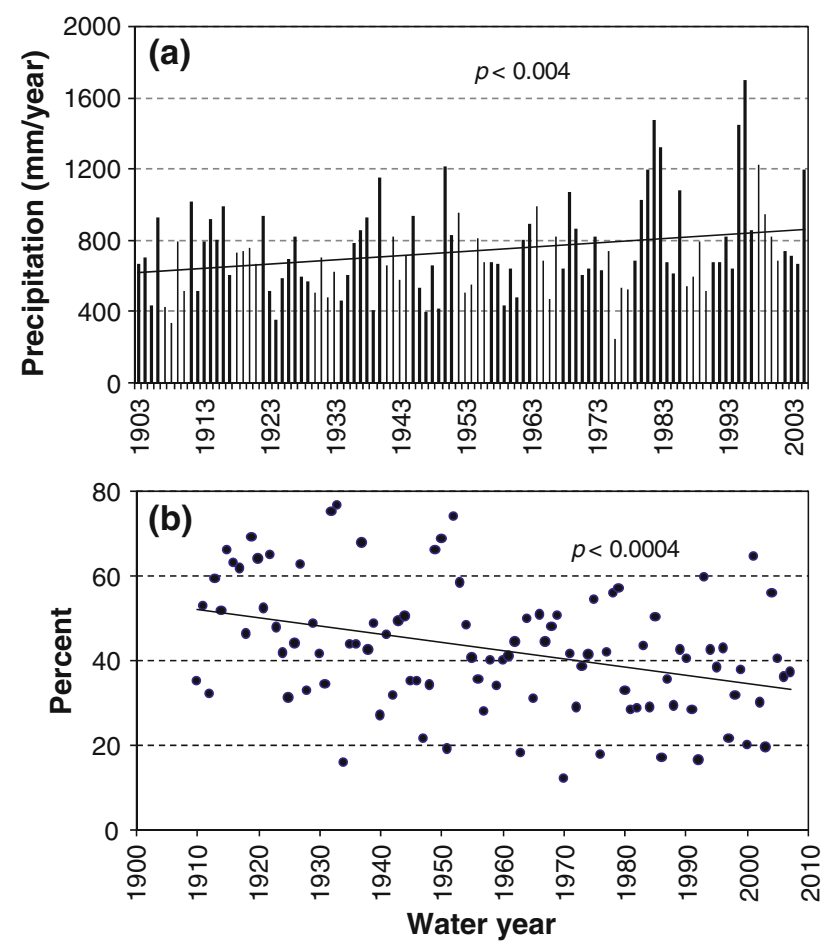

Fig. 3 a Annual precipitation and b percent of total annual precipitation falling as snow on a day with average temperature below freezing. The lines show the linear trends

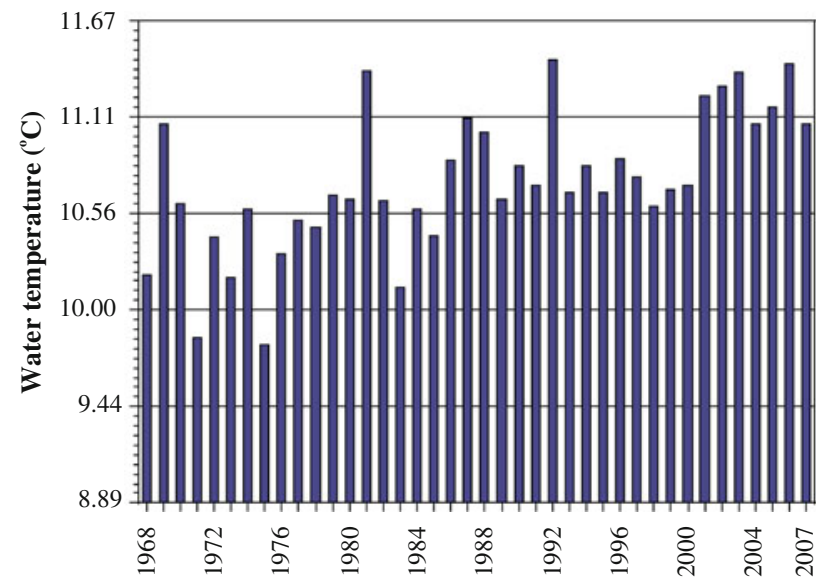

Fig. 4 Annual average surface temperature at mid-lake station (Source: UC Davis, TERC 2008, annual report)

the warming trend continues. Since deep mixing supplies dissolved oxygen from surface to bottom, reduced mixing may result in evolution of anoxic condition near the sediment interface.

Climate change is a long-term (decades to millennium) shift in the statistics of the weather. Climate change is a normal part of the earth's natural variability, which is related to interactions among the atmosphere, ocean, and land, as well as changes in the amount of solar radiation reaching the earth. Global warming, the rise in global atmospheric temperature due to an increasing heat-trapping gas emissions (e.g. $\mathrm{CO}_{2}$ emission from vehicles, industry, power plants, and deforestation) in the atmosphere, is the primary cause of climate change. The Fourth Assessment Report of the Intergovernmental Panel on Climate Change (IPCC 2007) indicates that: (1) there is high agreement and much evidence that, with current climate change mitigation policies and related sustainable development practices, global green house gas (GHG) emissions will continue to grow over the next few decades; and (2) continued GHG emissions at or above current rates would cause further warming and induce many changes in the global climate system during the twenty-first century. Therefore, the objectives of this study are: (1) to assess the future trends of climatic variables (e.g. air temperature, precipitation, wind speed, longwave radiation, and solar radiation) using predictions of three General Circulation Models; (2) to estimate the thermal properties and maximum mixing depth of Lake Tahoe using the hydrodynamics modules of Lake Clarity Model (developed by researchers at UC Davis); and (3) to discuss future possible implications on water quality due to changes in thermal properties in the lake.

\section{Facts about Lake Tahoe}

The physical setting of Lake Tahoe (approximately $38^{\circ} 56^{\prime} 12.10^{\prime \prime} \mathrm{N}-39^{\circ} 14^{\prime} 22.41^{\prime \prime} \mathrm{N}$ and $119^{\circ} 55^{\prime} 40.48^{\prime \prime} \mathrm{W}-120^{\circ}$ $09^{\prime} 53.33^{\prime \prime} \mathrm{W}$ ) is striking. It is situated near the crest of the Sierra Nevada Mountains at an elevation of approximately $1897 \mathrm{~m}$ above sea level. Lake Tahoe is the eleventh deepest lake in the world, with a maximum and an average depth of 500 and $305 \mathrm{~m}$, respectively. The maximum width and length of Lake Tahoe are 19.3 and $35.4 \mathrm{~km}$, respectively. The lake has a surface area of $501 \mathrm{~km}^{2}$ within a watershed of $813 \mathrm{~km}^{2}$. The total volume of the lake is $158 \mathrm{~km}^{3}$ with a mean hydraulic residence time of 650-700 years. The basin consists of a total of 63 inflow tributaries, one outflow tributary, and numerous intervening zones that drain into the lake but not within the channels of the 63 tributaries (Fig. 5). Flow from ten major streams (Upper Truckee River, Ward Creek, Trout Creek, Third Creek, Logan House Creek, Incline Creek, Glenbrook Creek, General Creek, Edgewood Creek, and Blackwood Creek) are regularly monitored as part of the Lake Tahoe Interagency Monitoring Program (LTIMP); these 10 tributaries (Fig. 5) account for up to $40 \%$ of the total annual stream discharge into the lake.

Over $90 \%$ of precipitation in the lake watershed occurs as snow at the higher elevations; at lake level, both rain and snow fall in significant amounts (Perez-Losada 2001). The 


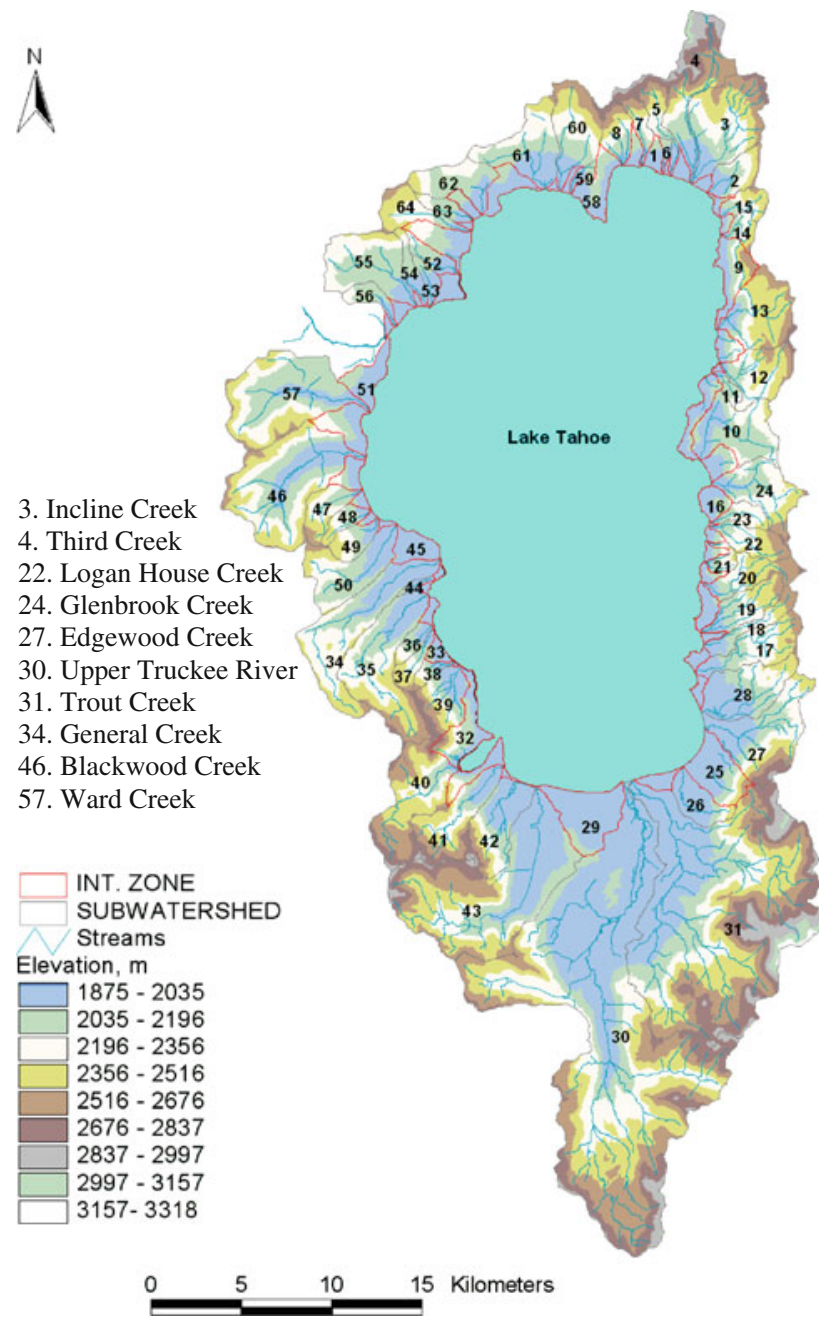

Fig. 5 Lake Tahoe and the locations of all the 64 streams. Names and corresponding map IDs of 10 LTIMP streams are shown at the lefthand side. The stream without a map ID represents Truckee River, the only outflow to Lake Tahoe

greatest transport of sediment and some associated nutrients occurs during high flows caused by storms and snowmelt (Hatch et al. 2001). The high residence time allows for internal nutrient and sediment cycling.

\section{Methods}

\subsection{Lake clarity model}

To examine the impact of global warming and climate change on Lake Tahoe, the lake clarity model (LCM) is used as a tool to simulate the lake dynamics. The LCM (Sahoo et al. 2007a, b) is a complex system of sub-models, including thermodynamic, hydrodynamic, ecological, zooplankton, nutrient, particle, and optical sub-models, although only the thermodynamic and hydrodynamic

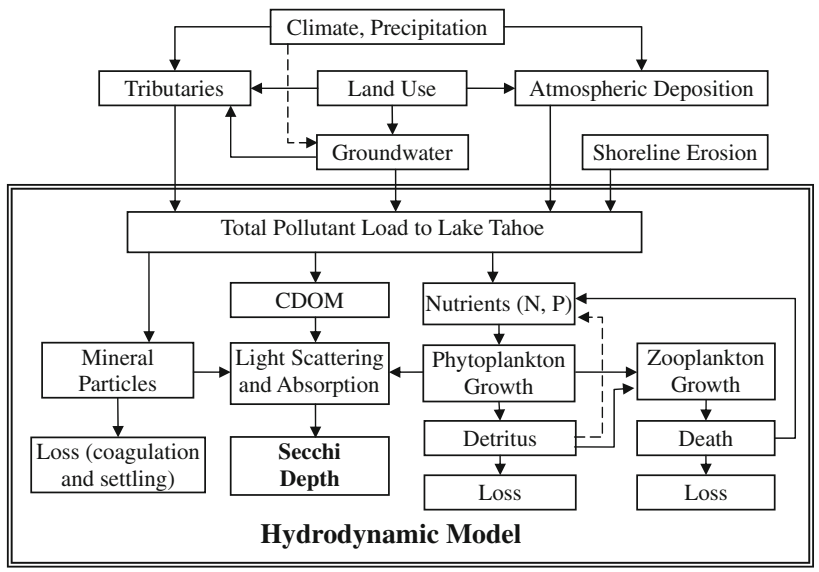

Fig. 6 Schematic diagram of lake clarity model (LCM). The double line box includes all in-lake processes and a hydrodynamic model

modules are used for the present study. The conceptual design of the LCM is shown in Fig. 6. All the LCM submodels operate inside the double line box in Fig. 6 . The pollutant sources and amounts of inorganic particle loading from atmospheric deposition, groundwater, tributaries, and various land uses (urban and non-urban) are shown at the top of the double line box. Groundwater contributes only nitrogen and phosphorus for algal growth. The optical sub-model estimates Secchi depths based on scattering and absorption characteristics of particles, algae, colored dissolved organic matter (CDOM), and water itself.

The LCM requires daily meteorologic data, such as solar shortwave radiation $\left(\mathrm{kJ} / \mathrm{m}^{2} /\right.$ day $)$, incoming longwave radiation $\left(\mathrm{kJ} / \mathrm{m}^{2} /\right.$ day) or a surrogate, such as fraction of cloud cover and air temperature $\left({ }^{\circ} \mathrm{C}\right)$, vapor pressure (mbar) or relative humidity $(\%)$, wind speed $(\mathrm{m} / \mathrm{s}$ at $10 \mathrm{~m}$ above the water surface), and precipitation (mm, 24-h total). Hourly data from 1994 to 2004 were collected at Tahoe City meteorologic station (SNOTEL gage maintained by the United States Natural Resources Conservation Services: $39.172^{\circ} \mathrm{N}$ latitude and $120.138^{\circ} \mathrm{W}$ longitude). The hourly recorded data are then further averaged or integrated as necessary to obtain daily values.

In-lake vertical profiles of temperature, chlorophyll $a$, dissolved oxygen (DO), biological oxygen demand (BOD), soluble reactive phosphorous (SRP), particulate organic phosphorus (POP), dissolved organic phosphorus (DOP), nitrate $\left(\mathrm{NO}_{3}\right)$ and nitrite $\left(\mathrm{NO}_{2}\right)$, ammonia $\left(\mathrm{NH}_{4}\right)$, particulate organic nitrogen $(\mathrm{PON})$, dissolved organic nitrogen (DON), and concentrations of seven classes of particles collected at the mid-lake station (i.e. in the deeper part of the lake, $460 \mathrm{~m}$ deep) are used for LCM calibration and validation purposes and as initial profile for lake simulation. The daily input values for all 63 
streams are generated by the Loading Simulation Program in C ++ (LSPC) (Tetra Tech Inc. 2007). Outflow of Lake Tahoe into the Truckee River is regulated by a dam at Tahoe City (California). The outflow records available at the United States Geological Survey site (http://water data.usgs.gov/ca/nwis/sw) are used in this exercise. The values of groundwater discharge and nutrient loading to Lake Tahoe reported in United States Army Corps of Engineers (USACOE 2003) are used in this study. Adams and Minor (2002) estimated annual average nutrient and inorganic particulate matter load to Lake Tahoe as shoreline erosion based on aerial images of two different years (1938 and 1998). These annual average loads are divided into number of days of a year for daily load to the lake. The California Air Resources Board (CARB 2006) conducted the Lake Tahoe Atmospheric Deposition Study (LTADS) to quantify atmospheric deposition from nitrogen, phosphorus, and particulate matter loading into Lake Tahoe. Estimates of wet deposition came from the UC Davis-Tahoe Environmental Research Center (TERC) monitoring. Phosphorus deposition was also estimated by the UC Davis DELTA Group (Cahill 2006; Gertler et al. 2006) and the UC Davis-TERC (Hackley et al. 2004, 2005). Nitrogen deposition was estimated by the Desert Research Institute (DRI), Reno, Nevada, and UC Davis-TERC. Deposition of particulate matter was done by CARB (2006). The nutrients and particulate matter loads from atmosphere, groundwater discharge, and shoreline erosion are kept the same for all the simulation years because these are the best estimates available at present. Atmospheric and ground load vary seasonally in a year. However, the daily shoreline erosion rate is the same round the year because only annual average estimates are available. With this set up, the LCM is calibrated and validated using the measured in-lake vertical profiles during 2000-2002. The water temperature contour plots (Fig. 7) show that the simulated temperature values are close to the measured values. Because lake water temperature profiles are measured at 0 (surface), 10, 50, 100, 150, 200, 250, 300, 350, 400, and $450 \mathrm{~m}$, as shown in Fig. 7, temperatures at other depths are estimated by linear interpolation between neighboring points. Because of interpolation, the colored contoured portions in case of measured temperature contour are seen expanded. However, simulated water temperatures are written at every $5 \mathrm{~m}$ depth. Figure 7 indicates that the lake clarity model simulates lake dynamics well. Detailed calibration and validation results are also available in Roberts and Reuter (2007) and Sahoo et al. (2007b). The calibrated and validated LCM is used to examine the Lake Tahoe's future (i.e. 2005-2040) thermal properties and mixing dynamics due to climate change.
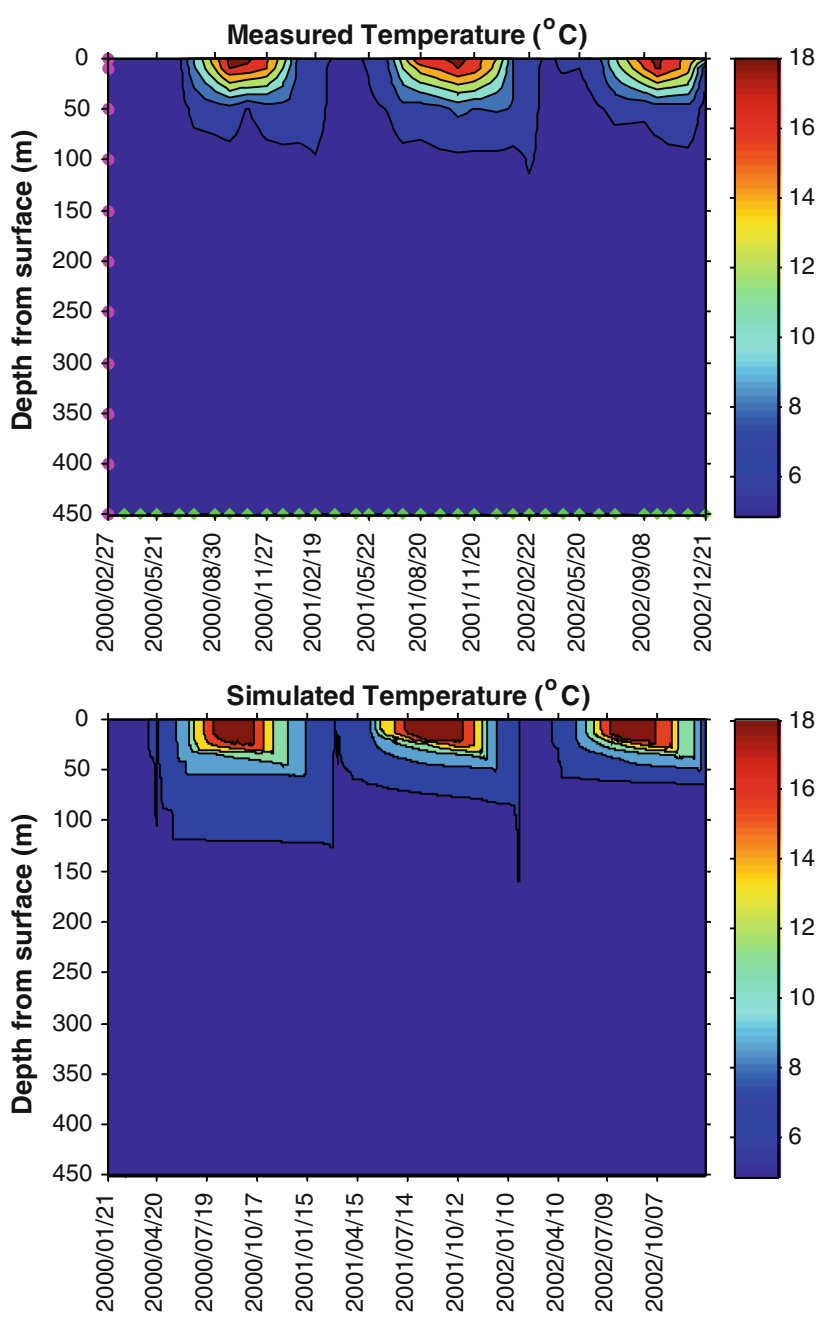

Fig. 7 Measured and simulated temperature contours for years 20002002. The circular magenta symbols on the Y-axis of the upper figure represent the measured data points at different depths from the surface and diamond green symbols on the $\mathrm{X}$-axis represent the measured day

\subsection{Future 41-year scenario}

To run the lake clarity model, a series of simulation years into the future (41-year period i.e. 2000-2040) is established. This time period is selected for example purposes only to examine the effect of global warming and climate change on Lake Tahoe. Since a principal driving force for watershed loading and lake clarity is annual precipitation (Jassby et al. 2003), the annual total precipitation for the period 1968-2005 is analyzed to establish a realistic scenario for future years (the Lake Clarity Model requires precipitation values for those years to be simulated).

Flow from ten streams (Upper Truckee River, Ward Creek, Trout Creek, Third Creek, Logan House Creek, Incline Creek, Glenbrook Creek, General Creek, Edgewood Creek, and Blackwood Creek) are regularly 
monitored as part of the Lake Tahoe Interagency Monitoring Program (LTIMP); these 10 tributaries (Fig. 5) account for up to $40 \%$ of the total annual stream discharge into the lake. Although LTIMP became operational in Water Year 1980 (Leonard and Goldman 1981), for many years depth-integrated temperature and water quality data are only available on an event basis with sampling frequency on the order of 25-30 times per year (Rowe et al. 2002). In collaboration with USGS, LTIMP Stream Monitoring Program has been producing streamflow and nutrient and suspended sediment concentrations data for tributaries to Lake Tahoe since 1988. These field samples are analyzed for nitrogen, phosphorus, and suspended sediment, and annual loads are calculated based on the continuous flow hydrographs recorded at each site (Rowe et al. 2002). The loading simulation program in $\mathrm{C}++$ (LSPC) watershed model (Tetra Tech Inc. 2007) is calibrated and validated based on the available 11 years (1994-2004) of LTIMP complete field data.

The LSPC watershed model provides stream inputs (i.e. inflow) for the period 1994-2004. Since, lake clarity model needs inflow to the lake and outflow from it, the precipitation information (and associated LSPC loading results) from these 11 years (i.e. 1994-2004) is used to populate the LCM runs for the period 2000-2040. In the precipitation distribution, future precipitation years are randomly chosen from these 11 years, so that: (1) the proposed precipitation frequency distribution for the period of 2000 2040 closely matches with that of the period 1968-2005 (Fig. 8); (2) future precipitation distribution (2000-2040) should not contain either wet or dry years more than 2 years in a row; and (3) the maximum mixing depth frequency pattern of future years closely matches with that of the period 1973-2007 (further details are presented in Sect. 4). Note that TERC (2008) estimated, using the

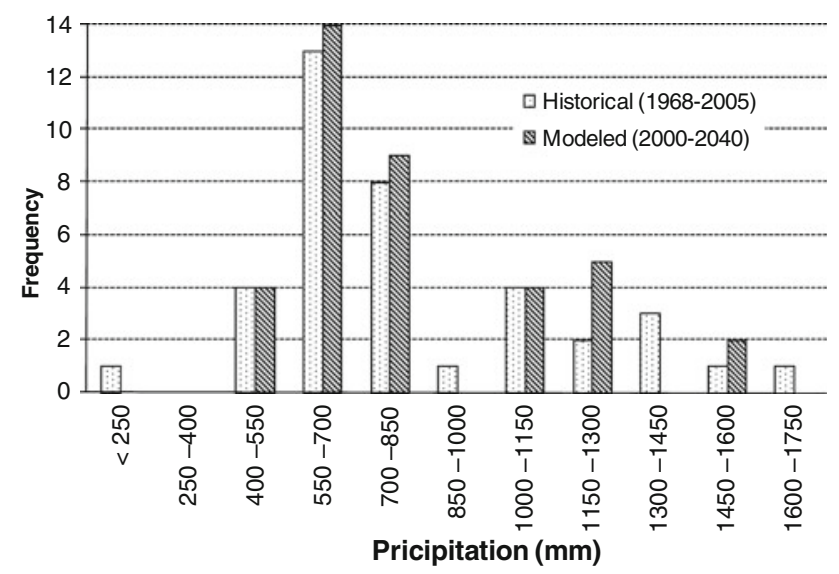

Fig. 8 Historical (1968-2005) and modeled (2000-2040) annual precipitation frequency distributions in-lake measured profiles of the period 1973-2007, that deep mixing occurred once in approximately 3 years. Sahoo et al. (2009) developed a subroutine to estimate stream temperature from air temperature and solar radiation. In the 40-year simulation period, the stream temperature is changed because of the change in air temperature. However, the streamflow and the associated loads are kept the same. In our future study, we will incorporate the change in streamflow and the associated pollutant loads due to climate change.

\subsection{Future trends of climatic variables}

In lakes and reservoirs, the longwave radiation exchanges, sensible heat transfer, and the evaporative heat losses affect only the surface layer temperature (Fischer et al. 1979; Martin and McCutcheon 1999). Only the visible part of the solar spectrum $(0.36$ to $0.76 \mu \mathrm{m})$ effectively penetrates below the surface layer and supplies heat into the deeper part of the lake. Wind produces shear near the water surface and initiates motion in water. Mixing (i.e. deepening of epilimnion) takes place because of water movement. Precipitation on the lake changes temperature and lake volume of the surface layer. Therefore, trends of GCM-predicted weather variables, such as downward shortwave radiation, longwave radiations, air temperature, wind speed, and precipitation, are calculated.

The trends of the twenty-first century weather variables for the modeling grid that includes Lake Tahoe are estimated using predictions of three GCMs: (1) Model for Interdisciplinary Research on Climate V. 3.2 High Resolution (MIROC-HIRES), Japan; (2) the National Center for Atmospheric Research, Community Climate Model (NCAR CCM V. 3.0); and (3) the National Oceanic and Atmospheric Administration (NOAA) Geophysical Fluid Dynamics Laboratory V CM2.1 (NOAA GFDL CM2.1). The modeling latitude and longitude resolutions of the MIROC-HIRES, NCAR CCM V3.0, and NOAA GFDL CM2.1 models are $160 \times 320$ (i.e. $1.125^{\circ} \times 1.125^{\circ}$ ), $128 \times 256$ (i.e. $1.14^{\circ} \times 1.14^{\circ}$ ), and $90 \times 144$ (i.e. $2.0^{\circ} \times 2.5^{\circ}$ ), respectively. The National Institute of Environmental Studies (NIES), Japan report that they have not carried out the A2 IPCC special report on emission scenario (SRES) experiment for the MIROC-HIRES Model (personal communication with Manabu ABE, NIES, Japan during September-October, 2008). On our request, NIES, Japan provided daily weather variables for B1 SRES experiment data. For the other two GCM models, we download data for A2 SRES experiments from the respective data portal sites (http://nomads.gfdl.noaa.gov/ CM2.X/, http://www.earthsystemgrid.org/). 


\section{Results and discussion}

\subsection{Future trend of climatic variables}

The slopes of trend lines for air temperature $\left({ }^{\circ} \mathrm{C}\right)$, net longwave radiation $\left(\mathrm{W} / \mathrm{m}^{2}\right)$, downward shortwave radiation $\left(\mathrm{W} / \mathrm{m}^{2}\right)$, annual precipitation ( $\left.\mathrm{mm} / \mathrm{year}\right)$, and wind speed $(\mathrm{m} / \mathrm{s})$ for the twenty-first century (2001-2100) are calculated using GCM predictions. To cancel out seasonal variations, 1-year moving average values are presented, except for precipitation, in Figs. 9, 10, and 11. For the case of precipitation, 5-year moving average annual precipitation values are shown. Slopes of trend lines (Figs. 9, 10, 11) suggest that: (a) air temperature will increase by $4.0-5.5^{\circ} \mathrm{C}$; (b) net longwave radiation will increase approximately by $1-10 \%$; (c) downward shortwave radiation will have no significant change; and (d) wind speed will decrease approximately by $0.5-10 \%$. Figure $10 \mathrm{~b}$ indicates that annual precipitation will decrease approximately by $25 \%$ for the GFDL A2 scenario. However, past records at Tahoe City meteorologic station (Fig. 3a) and
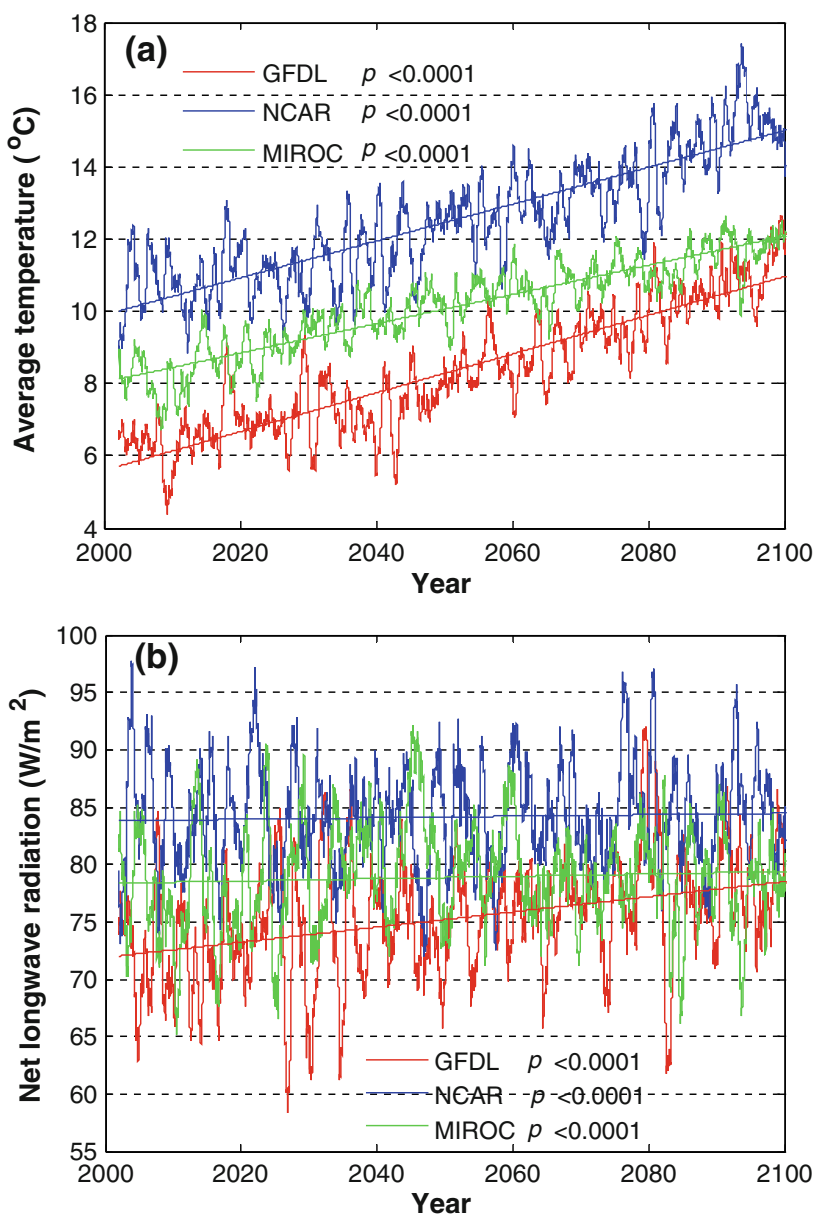

Fig. 9 One-year moving average trends of a average air temperature and $\mathbf{b}$ net longwave radiation for the GCM grid cell that includes Lake Tahoe. Predictions of three GCMs data are used for the trends
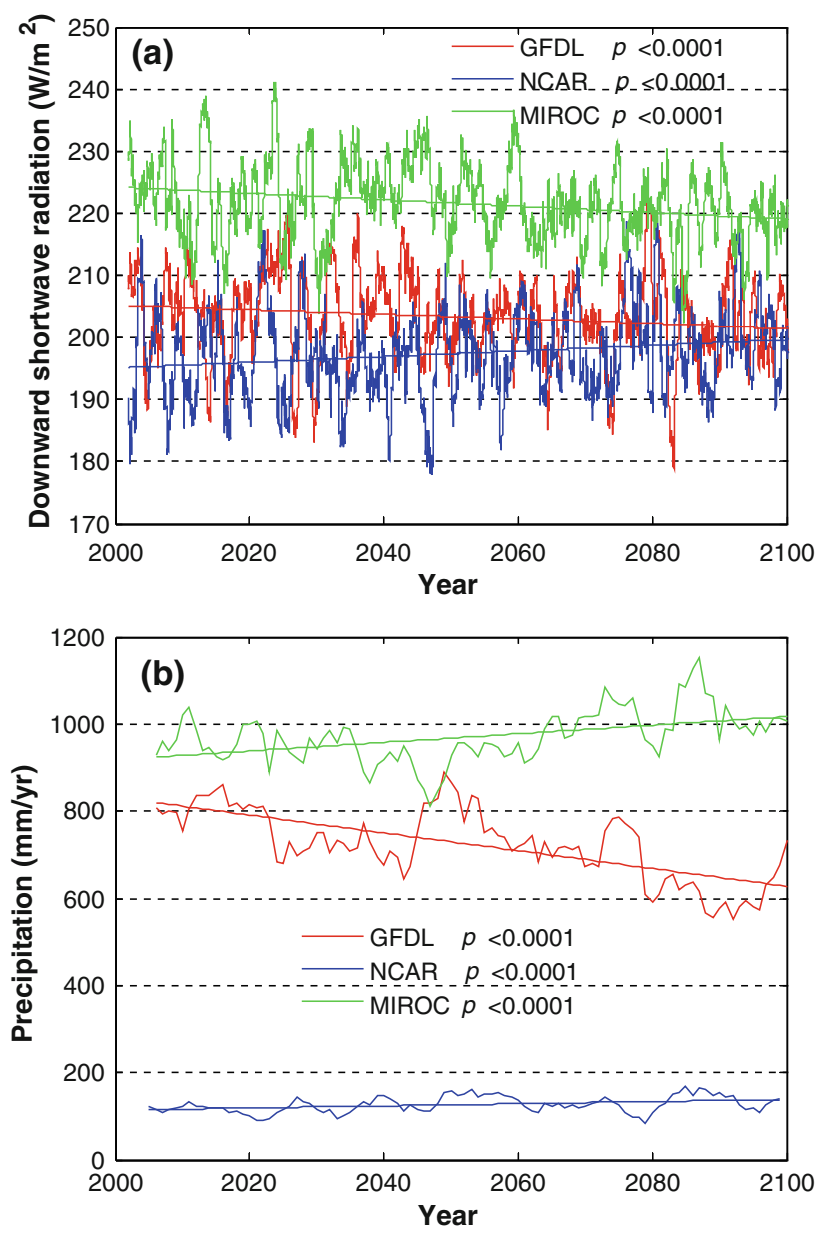

Fig. 10 Trends of a one-year moving average downward shortwave radiation and $\mathbf{b}$ five-year moving average annual precipitations for the GCM grid cell that includes Lake Tahoe. Predictions of three GCMs data are used for the trends

other two GCMs (MIROC-HIRES and NCAR CCM V. 3.0) predictions show increasing trends. The net change during the twenty-first century using IPCC SRES scenarios of GCM data and the percentage change based on trend lines are presented in Table 1.

Table 1 and Figs. 9, 10, 11 suggest that each GCM considered in this study produces different slopes of trend lines. This implies that the future trend for the 40-year simulation run should be within these ranges; however, trend values should be selected so that future simulated lake warming trend would be consistent with the historic warming trend. We use observed meteorologic data for years 2000-2004. Values of progressive net change in weather are added to the 2005-2040 year data for future modeling simulation runs. Each year, a fixed value is added to weather variables. For example, the change in air temperature $(\Delta \mathrm{T})$ in a year is $(1.6 / 35) \times($ Year -2005$)$. The net change selected in this study for air temperature, longwave radiation, wind speed, and precipitation during 2005-2040 are $+1.6^{\circ} \mathrm{C},+7 \%,-5 \%$, and $-30 \mathrm{~mm}$, 

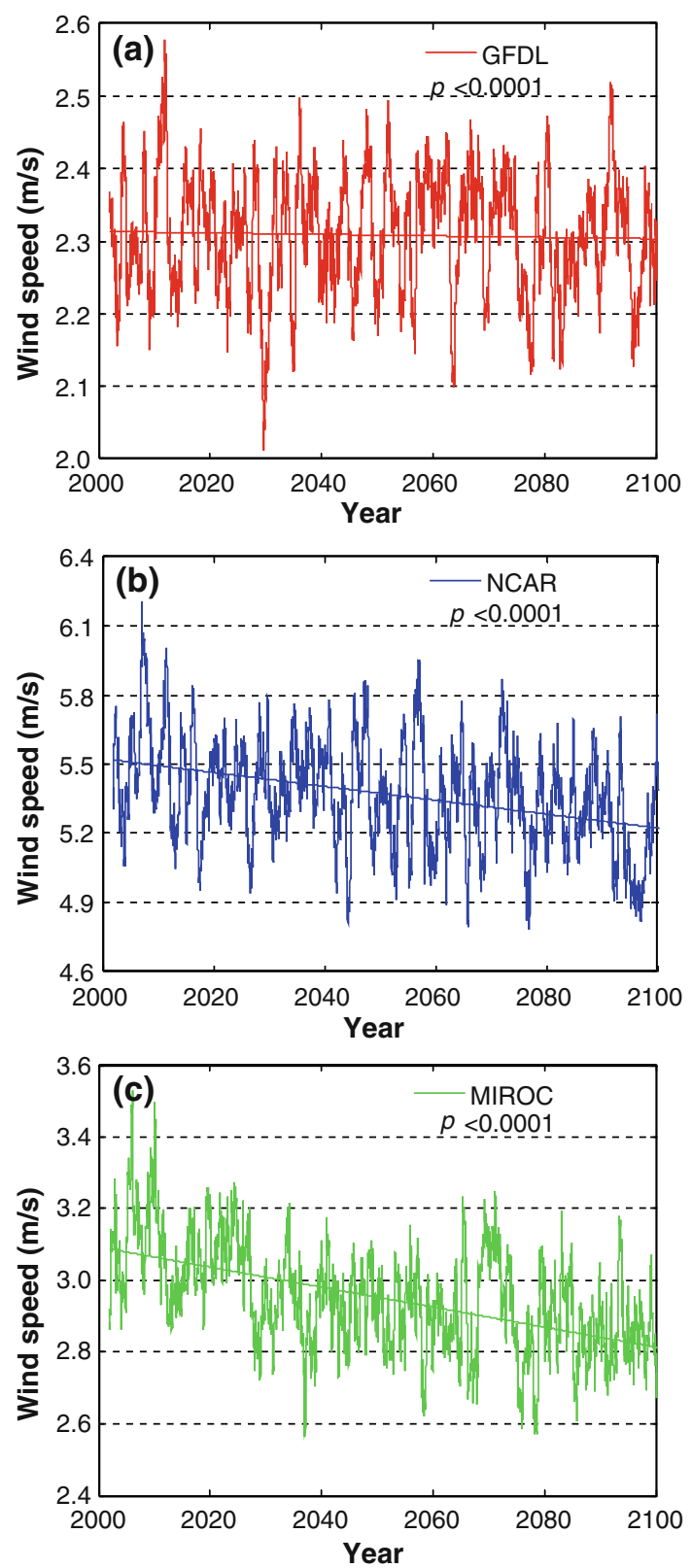

Fig. 11 Trends of one-year moving average wind speed for the GCM grid cell that includes Lake Tahoe. Predictions of three GCMs data were used for the trends respectively. The positive and negative signs indicate increasing and decreasing trend, respectively. These values are selected for example purpose so that: (1) the volumeweighted average temperature will closely match with the historical observed volume-weighted average temperature (i.e. $0.013^{\circ} \mathrm{C} /$ year); and (2) the net change in weather will be well within the GCM-predicted range. One could arrange a number of combinations for the net change in weather variables. Because future changing rate is uncertain, we select, for example purpose, one combination that would produce historical lake warming trend. The main reason for such a selection is to answer the question-what will happen to the lake's thermal properties with continued climate change at historical lake warming rate? Our future study will estimate the trends of downscaled $12 \times 12 \mathrm{~km}$ weather variables and will use downscaled GCM predictions in the simulation.

\subsection{Lake warming and stability change}

With the assumptions made in Sect. 4.1, the LCM estimates the volume-weighted warming trend of Lake Tahoe approximately $0.013^{\circ} \mathrm{C} /$ year for the period $2005-2040$, as presented in Fig. 12. To cancel out the seasonal variations, 1 -year moving averages of daily values are presented. This finding is consistent with the value estimated by Coats (2008) and by Sahoo and Schladow (2008). In making such comparison between the studies, it is also relevant to highlight the differences between the present study and that of Sahoo and Schladow (2008). In essence, there are three major differences. First, Sahoo and Schladow (2008) used values of net changes in air temperature and precipitation of future 41 years based on the estimates reported by Cayan et al. (2008) for northern California using GFDLpredicted temperature and precipitation changes during the twenty-first century for A2 emission scenario. Second, they used $10 \%$ net change in longwave radiation for the period 2005-2040, which is at the upper range value for the period 2000-2100. Third, they did not make any changes to the wind speed data. In addition to these, the present study also provides many other details when compared to Sahoo and

Table 1 Approximate change in weather estimated from trend lines of Figs. 9, 10, and 11 during the twenty-first century

\begin{tabular}{lllllll}
\hline Name of GCM & IPCC SRES experiment & $\Delta \mathrm{T}\left({ }^{\circ} \mathrm{C}\right)$ & $\Delta$ NWLR $\left(\mathrm{W} / \mathrm{m}^{2}\right)$ & $\Delta \mathrm{DSWR}\left(\mathrm{W} / \mathrm{m}^{2}\right)$ & $\Delta \mathrm{PRECIP}(\mathrm{mm} / \mathrm{year})$ & $\Delta \mathrm{WIND}(\mathrm{m} / \mathrm{s})$ \\
\hline GFDL & A2 & $5.5(100 \%)$ & $7.0(9.7 \%)$ & $-2.0(-0.98 \%)$ & $-200(-25 \%)$ & $-0.01(-0.4 \%)$ \\
NCAR & A2 & $5.0(50 \%)$ & $1.0(1.2 \%)$ & $4.0(2.05 \%)$ & $10(6.7 \%)$ & $-0.30(-5.5 \%)$ \\
MIROC & B1 & $4.0(50 \%)$ & $2.0(2.6 \%)$ & $-6.0(-2.7 \%)$ & $100(11 \%)$ & $-0.30(-9.7 \%)$ \\
\hline
\end{tabular}

The values in parentheses represent the percentage change based on the beginning value of the trend lines. Abbreviations: $\Delta \mathrm{T}, \Delta \mathrm{NWLR}$, $\triangle \mathrm{DSWR}, \triangle \mathrm{PRECIP}$, and $\triangle \mathrm{WIND}$ represent change in air temperature, net longwave radiation, downward shortwave radiation, precipitation, and wind speed, respectively 
Schladow (2008), as is clear from the explanations in the Sects. 1 and 4. Figure 7 shows that the lake hypolimnion layer starts about $100 \mathrm{~m}$ deep from the surface when the lake is strongly stratified. So, the volume-weighted warming trends of the lake upper $100 \mathrm{~m}$ and the water column below $100 \mathrm{~m}$ from the surface are shown in Fig. 12. The slopes of the trends show that the upper $100 \mathrm{~m}$ of the water column warms at a faster rate than the water column below $100 \mathrm{~m}$. Livingstone (2003) found similar warming trends for epilimnion and hypolimnion layers of the Lake Zurich. A close view of daily lake surface temperature for the cases with and without climate change is shown in Fig. 13. The change in surface temperature during summer is significantly higher than those of the other three seasons. This implies that higher evaporative loss is expected during summer season in the case of continued climate change when compared to the no climate change case. This observation is very significant for water resources management of reservoirs and shallow lakes.

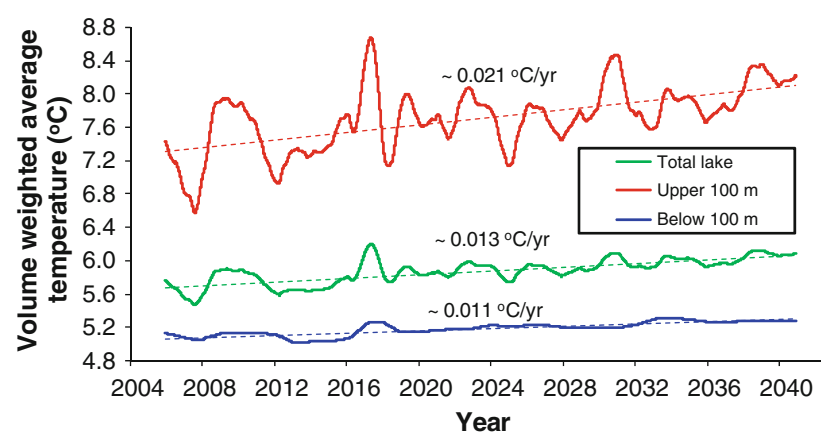

Fig. 12 One-year moving average and volume-weighted average water temperatures of the lake upper $100 \mathrm{~m}$, below $100 \mathrm{~m}$ to bed, and total lake. The thin dashed lines represent linear trends. The values near to each trend line show the increase in lake water temperature per year. A one-year moving average of daily values is used to reduce the influence of natural seasonal fluctuations

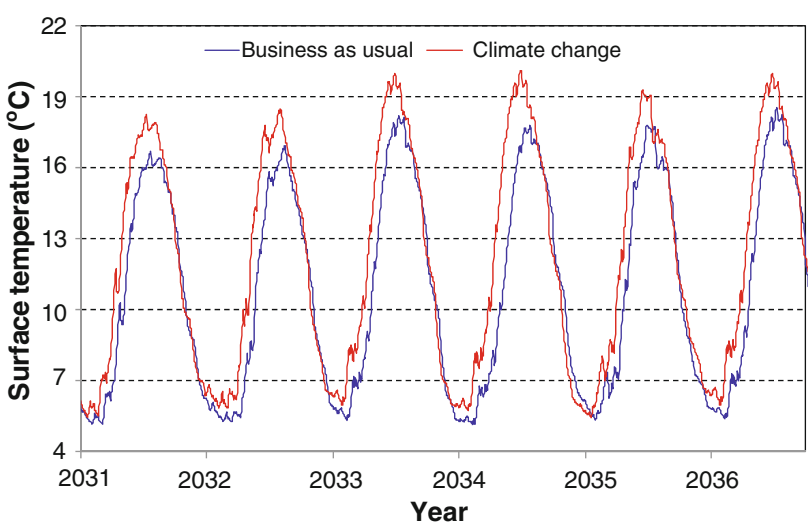

Fig. 13 Close view of simulated daily surface temperature for the cases 'business as usual' (i.e. current trend) and 'climate change' scenarios considered in this study
During the 40-year simulation period, the lake demonstrates complete mixing to the bottom during 13 individual years if there is no change in the GCM parameters used in the lake hydrodynamic model (Fig. 14). A deep mixing frequency of approximately one in 3 years is consistent with the long-term record (TERC 2008). Each bar in Fig. 14 shows the maximum mixing depth occurred in that year (Maximum mixing depth is the depth from the water surface up to which the water column is isothermal). Modeling results indicate that, with continued global warming and climate change, deep mixing $(>300 \mathrm{~m}$ ) or full mixing (up to the bottom) could cease after 2019. The lake stability estimated in terms total work and Schmidt stability $\left(\mathrm{kJ} / \mathrm{m}^{2}\right)$ increases (Fig. 15). Lake stability is the amount of work needed for a water column to overcome thermal stratification and, hence, vertical density differences in order to completely mix. Schmidt stability is the amount of work needed to be done by the wind for a water column to overcome thermal stratification and, hence, vertical density differences in order to completely mix. Estimation of Schmidt stability requires surface area, area at each depth measured, the depth to the center of gravity for a stratified lake, total lake volume, and the density at each depth measured. Thus, lake stability increases and mixing reduces for increasing total and Schmidt work. This indicates that Lake Tahoe could become permanently stratified due to reduced mixing and increasing stability. Such a change would have profound impacts on the lake's biota.

The lake warming and mixing pattern will change when the assumptions for the rate and magnitude of meteorologic variables (e.g. air temperature, longwave radiation, wind speed) change. It should be noted that the results presented herein are valid only for the assumptions made. Thus, one should not take the present findings as predictions and/or estimations; rather, one should take a message that lake dynamics and thermal properties will change with continued climate change. The presented results are only preliminary, and further detailed research is required to ascertain these findings.

\subsection{Possible effects on lake due to warming trend}

The trends in the observed data during 1970-2007 and in the LCM estimation for the period 2005-2040 show that Lake Tahoe is warming at the rate of $0.013^{\circ} \mathrm{C} /$ year. With continued climate change, the lake might be permanently stratified and mixing would reduce. The significant possible effects on the lake will most likely be associated with the warming, increased thermal stability, and reduced mixing.

First, the dissolved oxygen holding capacity of the water decreases as temperature increases. Therefore, with increasing surface temperature, the solubility of gaseous 
Fig. 14 Maximum mixing depth in a year for the cases 'business as usual' (i.e. current trend) and 'climate change' scenarios considered in this study

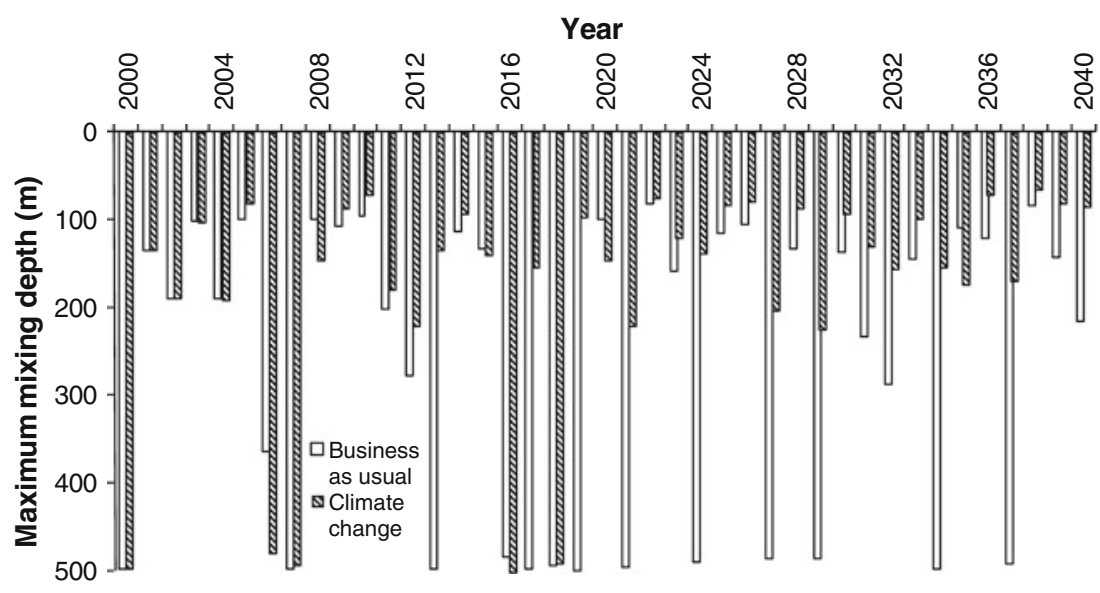

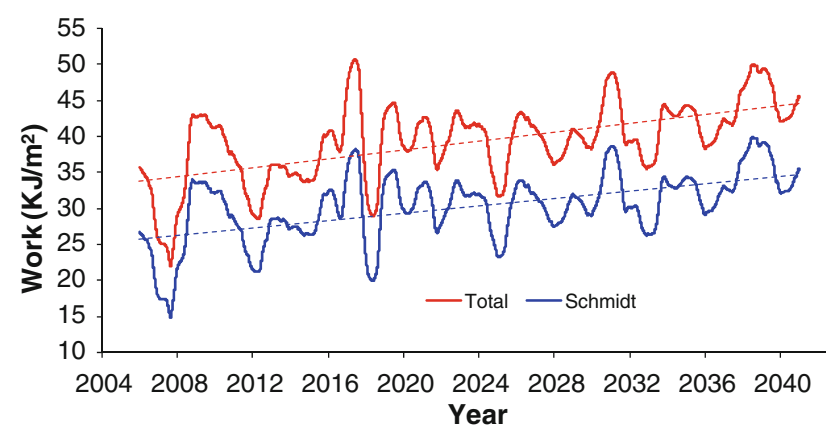

Fig. 15 One-year moving average total work and Schmidt stability in Lake Tahoe, with climate change scenarios considered in this study. The thin dashed lines represent linear trends

oxygen at the air-water interface decreases. Deep mixing occurs during winter once in approximately 3 years (TERC 2008). Thus, highly concentrated DO is transported from the epilimnion layer to the hypolimnion layer during deep mixing. Reduced mixing will shut down transport of dissolved oxygen from surface to the hypolimnion layer of the lake. Aquatic organisms, decay processes of dead algae and bacteria, and other pollutants (such as ammonia, nitrite, and particulate organic nitrogen) in water consume DO. Reduced mixing, increasing water temperature, and continuous consumption of DO would strip DO level to the minimum in the hypolimnion over time. This might result in hypoxia at the sediment surface in deep water, triggering solubilization of accumulated phosphorus and heavy metal in the sediments.

Second, the kinematics of many important elements in lake ecosystems, such as phosphorous, nitrogen, sulfur, silica, and iron, are dominated by microbial activity, which is controlled primarily by DO concentration (redox potential), temperature, $\mathrm{pH}$, and various concentrations of these elements. In general, increasing temperature accelerates reaction rates. Decreased redox potential caused by low DO availability affects many equilibrium reactions. Phosphorous $(\mathrm{P})$ cycle is sensitive to DO, particularly the near-bottom concentration. Even a short, extreme anoxic period near the bottom can induce $\mathrm{P}$ mobilization from the sediment to the water body, and change the lake permanently to eutrophic. With increasing temperature, the solubility of gases decreases and processes, such as denitrification and nitrogen fixation, are accelerated. Such changes will lead to many water quality problems in lakes.

Third, evaporation from the lake surface increases for increasing surface temperature. However, due to reduced wind speed, the evaporative losses may be lower. Estimation of the total evaporative loss due to rising temperature and reduced wind speed requires more detailed studies.

Fourth, reduced snowfall as percentage of precipitation and early snowmelt peak runoff indicate a longer summer period. In such a case, current lake gate operation (i.e. outflow) may need to be changed for necessary releases to downstream users of the Truckee River and for the maintenance of required lake water surface level.

Finally, fine $(<20 \mu \mathrm{m})$ inorganic sediment has been shown to play an important role in reducing the clarity of the lake (Swift et al. 2006; Sahoo et al. 2007b). This impact is greatest in years following heavy stream runoff, and is prolonged by an absence of deep-water mixing events (Jassby et al. 1999). Following mixing, the fine particles suspended at the upper layer are dispersed throughout the water column. As a result, fine particles at the epilimnion are pushed down to the bottom, and clarity is increased. Because settling velocity of fine particles is very low, they remain suspended in the upper layer of the water column for a prolonged period, unless they coagulate to form bigger particles and settle faster. In the absence of full or deep mixing, the reduced lake clarity may be prolonged following a heavy runoff that carries huge amounts of fine sediments to the lake. The above hypotheses will be examined in a future study. 


\section{Conclusions and future directions}

This study investigated the impact of climate change on Lake Tahoe. Trends in maximum and minimum daily air temperatures were calculated for the Tahoe City meteorologic station. Precipitation data at Tahoe City were analyzed for trends in form (rain versus snow) and intensity of rainfall. Daily streamflow data for gaging stations in the Tahoe basin were examined for trends in snowmelt timing. The results for the Tahoe basin indicate strong upward trends in air temperature, a shift from rain to snow, a shift in snowmelt timing to earlier dates, increased rainfall intensity, increased interannual variability in rainfall intensity, and continued increase in the temperature of Lake Tahoe. Trends in 38 years of records (1970-2007) suggest that Lake Tahoe is warming at an average rate of $0.013^{\circ} \mathrm{C} /$ year, and, as a result, its thermal stability and resistance to mixing are increasing.

Predictions from three GCMs (GFDL CM2.1, MIROCHIRES, and NCAR CCM V3.0) indicate that the average air temperature at Lake Tahoe would increase by approximately 1.6 and $5^{\circ} \mathrm{C}$ at the end of 2040 and 2099, respectively. The GCMs also indicate that net longwave radiation will increase by approximately $1-10 \%$, and wind speed will decrease by approximately $0.5-10 \%$. The GCMs' prediction trends show no significant change in downward shortwave radiation. Although, GFDL CM2.1 model shows negative trend for precipitation, trends of observed data at the Tahoe City meteorologic station and predictions of MIROC-HIRES and NCAR CCM V3.0 models show an upward trend. The combination of increased air temperature and longwave radiation and reduced wind speed resulted in Lake Tahoe warming at the rate approximately $0.013^{\circ} \mathrm{C} /$ year. Lake warming is associated with the increased thermal stability at the rate approximately $0.3 \mathrm{~kJ} / \mathrm{m}^{2} /$ year. Rising air temperatures account for only part of the lake's recent warming. Other climate variables, such as the change in longwave radiation and wind speed, are also causes of lake warming. Increasing lake stability resulted in resistance to deep mixing. It was shown that at the current rate of climate change specified in this study, Lake Tahoe will stop deep mixing after 2019. However, this change depends on future rate and magnitude of climate change. Reduced mixing and lake warming may have significant adverse impacts on lake ecosystems and aggravate the existing problems.

It must be noted that the results shown here are not predictions and/or estimations; rather, they are possible future scenarios. Future lake warming rate depends on the rate and magnitude of climate change as well as the success of on-going efforts to reduce the anthropogenic flux of nutrients to the lake. The present results and findings will most likely change when the rate and magnitude of the meteorologic variables change from the assumptions made in this study. Since climate change is inevitable, current lake management strategies should be integrated with new approaches and methodologies that can handle issues on water quality problems due to climate change. Research and development on lakes should focus on methodologies and approaches that can handle extreme uncertainties as well.

Acknowledgments We wish to acknowledge the efforts of the many faculty, staff, and students who have worked at Lake Tahoe in acquiring and maintaining the long-term data base that could be used to ground truth modeling results. We acknowledge National Institute of Environmental Studies (NIES), Japan, the National Center for Atmospheric Research, and National Oceanic and Atmospheric Administration (NOAA) for allowing us to use their GCMs' prediction data.

Open Access This article is distributed under the terms of the Creative Commons Attribution Noncommercial License which permits any noncommercial use, distribution, and reproduction in any medium, provided the original author(s) and source are credited.

\section{References}

Adams KD, Minor TB (2002) Historic shoreline change at Lake Tahoe from 1938 to 1998 and its impact on sediment and nutrient loading. J Coast Res 18(4):637-651

Austin JA, Colman SM (2007) Lake Superior summer water temperatures are increasing more rapidly than regional air temperature: a positive ice-albedo feedback. Geophys Res Lett 34:L06604. doi:10.1029/2006GL029021

Austin JA, Colman SM (2008) A century of temperature variability in Lake Superior. Limnol Oceanogr 53(6):2724-2730

Cahill T (2006) Revision of phosphorus deposition estimates to Lake Tahoe. Technical memo dated March 9, 2006. University of California Davis, DELTA Group, CA, USA, 2 pp

CARB (California Air Resources Board) (2006) Lake Tahoe atmospheric deposition study (LTADS). Final Report-August 2006. Atmospheric Processes Research Section, California Environmental Protection Agency (EPA), Sacramento, CA

Cayan DR, Maurer EP, Dettinger MD, Tyree M, Hayhoe K (2008) Climate change scenario for the California region. Clim Chang 87(Suppl 1):S21-S42

Zhang Q, Xu CY, Tao H, Jiang T, Chen, YD (2009) Climate change and their impacts on water resources in the arid regions: a case study of the Tarim River basin, China. Stoch Environ Res Risk Assess. doi:10.1007/s00477-009-0324-0

Coats R (2008) Climate change in the Tahoe basin: regional trends, impacts, and drivers. American Geophysical Union (AGU) fall meeting. Paper \# GC43C-757, 15-19 December 2008, San Francisco, USA

Coats R, Perez-Losada J, Schladow G, Richards R, Goldman C (2006) The warming of Lake Tahoe. Clim Chang 76:121-148

Fischer HB, List EJ, Imberger J, Brooks NH (1979) Mixing in inland and coastal waters. Harcourt Brace Lovanovich Publisher, p 483

Gertler AW, Bytnerowicz A, Cahill TA, Arbaugh M, Cliff S, Kahyaoglu-Koracin J, Tarnay L, Alonso R, Fraczek W (2006) Local air pollutants threaten Lake Tahoe's clarity. Calif Agric 60(2):53-58

Hackley SH, Allen BC, Hunter DA, Reuter JE (2004) Lake Tahoe water quality investigations: 2000-2003. Tahoe Research Group, 
John Muir Institute for the Environment, University of California Davis, CA, USA, $122 \mathrm{pp}$

Hackley SH, Allen BC, Hunter DA, Reuter JE (2005) Lake Tahoe water quality investigations: July 1, 2005-June 30, 2005. Tahoe Environmental Research Center, John Muir Institute for the Environment, University of California Davis, CA, USA, 69 pp

Hatch LK, Reuter JE, Goldman CR (2001) Stream phosphorus transport in the Lake Tahoe Basin, 1989-1996. Environ Monit Assess 69:63-83

IPCC (2007) Working Group II Contribution to the fourth assessment report, climate change (2007). Climate change impacts, adaptation and vulnerability. WHO and UNEP IPCC, Geneva. http://www.ipcc.ch/. Accessed 1 June 2008

Jassby AD, Goldman CR, Reuter JE, Richards RC (1999) Origins and scale dependence of temporal variability in the transparency of Lake Tahoe, California-Nevada. Limnol Oceanogr 44:282-294

Jassby AD, Reuter JE, Goldman CR (2003) Determining long-term water quality change in the presence of climatic variability: Lake Tahoe (USA). Can J Fish Aquat Sci 60:1452-1461

Leonard RL, Goldman CR (1981) Interagency Tahoe Monitoring Program: first annual report. Water year 1980. Tahoe Research Group, Institute of Ecology, University of California, Davis, p 82

Livingstone DM (2003) Impacts of secular climate change on the thermal structure of a large temperate central European lake. Clim Chang 57:205-225

Martin JL, McCutcheon SC (1999) Hydrodynamics and transport for water quality modeling. Lewis Publishers, Boca Raton, pp 1-794

McCormick MJ (1990) Potential changes in thermal structure andcycle of Lake Michigan due to global warming. Trans Am Fish Soc 119:254-264

O'Reilly CM, Alin SR, Plisnier P-D, Cohen AS, McKee BA (2003) Climate change decreases aquatic ecosystem productivity of Lake Tanganyika, Africa. Nature 424:766-768

Perez-Losada J (2001) A deterministic model for lake clarity: application to management of Lake Tahoe (California-Nevada), USA. PhD thesis, Universitat de Girona, Girona, Spain, 231 pp

Roberts DM, Reuter JE (2007) Lake Tahoe total maximum daily load, Technical Report CA-NV. California Regional Water Quality Control Board, Lahontan Region, CA, USA
Rowe TG, Saleh DK, Watkins SA, Kratzer CR (2002) Streamflow and water-quality data for selected watersheds in the Lake Tahoe basin, California and Nevada, through September 1998, U.S. Geological Survey Water Resources Investigations Report 02-4030, Carson City, Nevada, USA, 117 pp

Sahoo GB, Schladow SG (2008) Impacts of climate change on lakes and reservoirs dynamics and restoration policies. Sustain Sci 3(2):189-199. doi:10.1007/s11625-008-0056-y

Sahoo GB, Schladow SG, Reuter JE (2007a) Response of water clarity in Lake Tahoe (CA-NV) to watershed and atmospheric load. In: Proceedings of the fifth international symposium on environmental hydraulics, Tempe, Arizona

Sahoo GB, Schladow SG, Reuter JE (2007b) Linkage of pollutant loading to in-lake effects. Final Modeling report prepared for the Lahontan RWQCB and University of California Davis, CA, USA, $62 \mathrm{pp}$

Sahoo GB, Schladow SG, Reuter JE (2009) Forecasting stream water temperature using regression analysis, artificial neural network, and chaotic nonlinear dynamic models. J Hydrol 378:325-342. doi:10.1016/j.jhydrol.2009.09.037

Siliverstovs B, Ötsch R, Kemfert C, Jaeger CC, Hass A, Kremers H (2009) Climate change and modelling of extreme temperatures in Switzerland. Stoch Environ Res Risk Assess. doi: 10.1007/s00477-009-0321-3

Swift TJ, Perez-Losada J, Schladow SG, Reuter JE, Jassby AD, Goldman CR (2006) Water Quality Modeling in Lake Tahoe: linking suspended matter characteristics to Secchi depth. Aquat Sci 68:1-15

Tahoe Environmental Research Center (TERC), University of California, Davis (2008) Tahoe: state of the lake report 2008. http://169.237.166.248/stateofthelake/StateOfTheLake2008.pdf. Accessed February 2009

Tetra Tech Inc. (2007) Waterhed hydrologic modeling and sediment and nutrient loading estimation for the Lake Tahoe total maximum daily load. Final modeling report prepared for the Lahontan RWQCB and University of California Davis, CA, USA

USACOE (United States Army Corps of Engineers), Sacramento District (2003) Lake Tahoe basin framework study groundwater evaluation, Lake Tahoe basin, California and Nevada, USA 